\title{
Ambiances
}

anbiances Environnement sensible, architecture et espace urbain Redécouvertes | 2019

\section{Urban Atmospheres}

\section{Niels Albertsen}

Translator. Bülent Diken

\section{OpenEdition}

\section{Journals}

Electronic version

URL: http://journals.openedition.org/ambiances/2433

DOI: 10.4000/ambiances.2433

ISSN: 2266-839X

\section{Publisher:}

Direction Générale des Patrimoines - DAPA - MCC, UMR 1563 - Ambiances Architectures Urbanités (AAU)

\section{Electronic reference}

Niels Albertsen, « Urban Atmospheres », Ambiances [Online], Rediscovering, Online since 03 June 2019 , connection on 24 October 2019. URL : http://journals.openedition.org/ambiances/2433 ; DOI : 10.4000/ambiances. 2433

This text was automatically generated on 24 October 2019 .

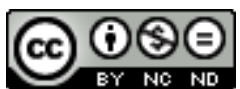

Ambiances is licensed under a Creative Commons Attribution-NonCommercial-NoDerivatives 4.0 International License. 


\title{
Urban Atmospheres
}

\author{
Niels Albertsen \\ Translation : Bülent Diken
}

\section{REFERENCES}

Albertsen, Niels. 1999. Urbane atmosfærer. Sosiologi i dag. Vol 29(4), p. 5-29.

On August 28, 1996, the old Maternity Hospital (Fødselsstiftelsen) in Aarhus closed. Expecting mothers, staff, and a lot of equipment were moved to the new, modern Skejby Hospital. The evening before, Regional-TV had covered this event with interviews with a couple that had a newborn and nurses. Everyone was pleased that there was now better space and more modern equipment in the new environment, but some were also a little worried about the future. Both the couple and a nurse put emphasis on the atmosphere of the old institution. The nurse was concerned about future cooperation: "Here is a special atmosphere; at skejby we cannot find each other." Likewise, the couple thought that it was a shame that it was no longer possible to give birth at the old birth house, explaining that "in such an old building there is a special atmosphere." While the nurse obviously associated the concept of atmosphere with the staff's social relations, all interviewees used the concept of atmosphere in a positive sense, and it was clear that atmosphere was considered to be significant for the wellbeing of both staff and patients.

2 The purpose of the following is to examine what the concept of atmosphere can mean and how it can be thought to contribute to the understanding of urban life and the aesthetics of cities. The reader must prepare for much speculation and conceptual discussion with little empirical analysis and documentation. Philosopher and science researcher Gernot Böhme (1995) puts forth the concept of atmosphere with a view to formulate a new aesthetics that does not take its point of departure from art. In the first section, I present various ontological and epistemological aspects of the concept. The following section takes issue with the significance of atmosphere for art and architecture. The third section examines, as a prelude to the discussion on urban 
atmospheres, Georg Simmel's concept of landscape, whose Kantian and artistic orientation seems to imply that there are no atmospheres in the metropolis. The fourth section takes the opposite position through discussions of smell, sound, and city life as well as the atmospheres of a modern city, city center, and urban region. In this respect, I consider mobility to be a decisive factor in relation to the atmosphere of the modern city and suggest that the atmosphere of the urban region could be depicted as a picturesque urban landscape for cyborgs. Further, communities in a city can be primarily atmospheric. The historic city can have an atmosphere of age, which can be felt without much historical knowledge, and the atmospheric can give rise to urban political conflict. To conclude, I focus on a discussion of the atmosphere of the city center in Dag Østerberg's recent book about Oslo. I claim that there can be found atmospheric aspects of a metropolitan region's socio-material action fields, which modify Østerberg's conclusions regarding the imaginary status of the center and the identity of a metropolitan region. The article's general thesis throughout is that atmospheres are an important and overlooked dimension of the relationships that people have within and with urban environments. ${ }^{1}$

\section{The concept of atmosphere}

\section{Atmospheric ontology}

3 Atmospheres are interesting and difficult to deal with. On the one hand, we are in no doubt that they exist. Our language use testifies to this fact. We can also distinguish between many kinds: serene, serious, terrifying, oppressive, the atmosphere of dread, of power, of the saint and the reprobate (Böhme, 1993, p. 123). We can talk about atmospheres between people, about political atmospheres, of atmospheres in urban space, architecture, and the natural landscape. On the other hand, we call them atmospheres because they are so strangely disembodied, indefinable, and elusive. Where is an atmosphere, really? Is it a property of things, does it belong to us, or is it something in between?

We do not get far by trying to locate atmosphere in the properties of things. We can say that a red material exudes a warm atmosphere, but we will not find heat by analyzing the red color or the more or less heat conductive properties of the material (Böhme, 1995, p. 55). And we do not get far locating the atmosphere in ourselves, as we sense that it is situated outside us. If we enter a room with a particular atmosphere, we are influenced by it and, as such, our mood changes. We do not project our mood onto space. On the contrary, the special atmosphere of the space affects us differently (Böhme, 1993, p. 119).

5 If we follow our experience with atmospheres, we must conclude that they exist between us and things determined by properties, between the subject and the object (Böhme, 1993, p. 114). But according to classical philosophical ontology, there is nothing to find between the subject and the object. There are either properties of the object or the subject and interactions between the subject and the object that can be traced back to each of these, or the projections of the subject onto the object. Yet we feel the atmospheres in between. There must therefore be something wrong with the subject-object distinction. If atmospheres are real we must understand the world differently, which applies to both things and humans. 
6 Human beings must be understood as sensuous bodies and not just as subjects endowed with consciousness and self-awareness. Atmosphere is something we perceive with all senses, something that affects us emotionally. Sensory observation is not limited to the observation of facts, but includes everything we understand about being in an environment. To sense an atmosphere is to be aware of how I, as a body, feel in an environment (Böhme, 1995, p. 15 and f.).

7 As far as things are concerned, we must break with the classical ontology of the thing, according to which a thing is a substance with associated properties that determine them as being different from other things with other properties. Along the same lines, the form of a thing is considered to be that which encloses its volume inwardly and delimits it outwardly. A thing, however, is not only a self-enclosed entity, it presents itself, makes its presence perceptible in its environment in certain ways and in particular forms. The form of a thing characterizes the form of the surroundings. A blue cup does not only have the property of being blue, it colors, so to speak, its surroundings with its blueness. Things are ecstatic, they step out of themselves and demonstrate their presence in the environment (Böhme, 1993, p. 120-123, translation modified). "Through its colored-ness each thing organizes space in its entirety, that is, enters into constellations with other things or centers the space by the superior power of its color and tones or tinctures at the same time all other things" (Böhme, 1995, p. 171). Similar is the case of the location of a thing in space. A thing does not only exist in a place, taking up a certain amount of space; it shows itself, in a constellation, to other things through distance and intermediary spaces, narrowness, and width, and its volume appears as opacity, as a surface that envelops a volume (Böhme, 1995, p. 168). ${ }^{2}$

Where, then, is atmosphere? It is situated between us and things, but not freely floating in the air. Atmosphere belongs to things and their properties in so far as they, as ecstasies, present themselves to the outside world in constellations with other things and properties. Indeed, atmosphere radiates from here. And it belongs to us, not as a psychic state we project onto things, but as something we trace or sense through our physical presence, because we perceive how we find ourselves bodily in our environment. "The atmosphere is the common reality of the perceiver and the perceived" (Böhme, 1993, p. 122). Atmospheres are not deities or demons hovering freely in the air and acting upon us, but they are nonetheless active. They grab us emotionally, put us in a mood, concern us, and characterize our state of being (Böhme, 1993, p. 120).

\section{Character, physiognomy, and sensory perception}

9 Atmospheres cannot be determined or defined in the same way as one can define a thing by determining its properties. Atmospheres are too vague and fluctuating. One can, however, describe things in their forms of presence and expression (Böhme, 1995, p. 174) and put the character of atmospheres into words to try to describe the connections between the ecstasies of things, atmospheres, and our states of being.

The ecstasies of things can be described by the ways in which they become manifest and distinguish themselves through contours, contrasts, discontinuities, and conciseness. They can also be described by the traits in their lines and forms, which cause the spectator to move his or her body in certain ways and create, actually or virtually, a sense of motion (Böhme, 1995, p. 140-141, 150). They can also be described 
by the ways in which they lead to synesthetic experiences, that is, cause us to describe our sensory input with words that refer to different sensory areas, e.g. warm color, raw voices, high or sharp, low or heavy tones (Böhme, 1995, p. 54, 85 and ff.), cold glass and steel, hot bricks.

The ecstasies of things can also have social character. Goethe (1810), for instance, in his Theory of Colours, mentions the "sensual-moral effect" of color. Things can radiate atmospheres that belong to certain life forms. Brilliance, splendor, and solidity are examples of life form-atmospheres that rest on socialization, cultivation, and conventions (Böhme, 1995, p. 55 and f, 78, 89).

Describing atmospheres, then, requires describing the forms of the presence of things in such a way that it becomes possible to connect these descriptions with perceptible atmospheres and states of being. Such descriptions apply to the character traits, or physiognomy, of materials, things, and environments (Böhme, 1995, pp. 55, 132 and ff.). They do not, however, attempt to deduce inner character from external physiognomy, and they do not seek an underlying interiority that expresses itself in the physiognomy of things. It is rather as in the art of acting in which character is made visible on the scene through mimicry, gestures, and words without spectators, therefore, drawing the conclusion that what they are presented is really the actor's personal character. In a theater, one senses the presence of human characters through the creation of an atmospheric effect, through a potential of impression that is experienced atmospherically (Böhme, 1995, p. 124, 135).

The concept of atmosphere involves, as already mentioned, all the senses. When we sense atmospheres, what is involved is not an individual sense, separately, but an interplay between senses, a "synthesis, for an individual and in a given moment, of multiple perceptions, which for the individual suggests the place that surrounds him," as Luc Adolphe (1998, p. 7) defines architectural or urban ambiance. Thus, the concept of atmosphere rehabilitates the other senses in relation to the usually dominant interest for sight in architecture and urbanism (p. 8). Atmosphere, however, is not only multi-sensory, it also has meaning or opinion as a major element. A good indoor climate is also multi-sensuous in that it combines light, sound, smell, humidity, and tactility in a way that is healthy and pleasant for human beings, but this does not in and of itself make an indoor climate an atmosphere. This whole becomes atmospheric first when we experience it as something more than an indoor climate, as a mood or disposition of the space, which has to do with character and physiognomy.

Atmosphere, then, exists in a border zone between sensuousness and meaning, between sensory experiences and the semiotic or hermeneutic. This is manifested in the fact that we can put an atmosphere into words. Yet this verbalization is not a decoding of a semiotic layer of meaning in the physical surroundings or an interpretation of the rhetorical demands that environments place upon us (Albertsen, 1993, p. 193, 197 and ff.). The verbalization is a message about the nature of the disposition or mood that a constellation of objects in the environment transports us into through our sensory perception. 


\section{Art, architecture, and atmosphere}

\section{Art and atmosphere}

15 Although a concept for aesthetics, the concept of atmosphere is not oriented toward art or artwork. It targets the increasing aestheticization of everyday life, politics, and economy and our relationship with nature as characterized by ecological problems (Böhme, 1995, p. 7). The term includes the diversity of the gestalts that surround us in our life world, both art and kitsch. "What is important is that each shaping of the world around us, any formation of the world's surface, is included in our state of being. Each room you are in, each flower wallpaper, each S-Bahn shape, each atmosphere in sales premises, etc. are aesthetics" (Böhme, 1995, p. 15).

16 Nevertheless, the concept of atmosphere corresponds to a "primary direction in the development of modern art," namely "parting with the work" (translation modified) after avant-garde art. The concept of atmosphere, after all, is not concerned about the self-circumscribed form, but "scenes, life spaces and charisma," which also applies to the performance and event art (Böhme, 1998, pp. 114-15). When visual art "does not represent anything, says nothing and means nothing," when in music "the timbre, dynamics and gestalt of the individual tone" becomes more important than melody, chords, and the temporal course, when in literature "the linguistic event" comes into the foreground for the meaning, then it is aesthetics of sensory experience, not significance or meaning (semiotics and hermeneutics), or the ineffable, that is called upon (Böhme, 1995, pp. 8-9). Even though images do not represent, say, or do anything, "important, sometimes dramatic experiences with them" are possible. Claiming that Barnett Newman's pictures produce "exactly the ineffable" is an "ad-hoc solution" (Böhme, 1995, pp. 8-9) When the concept of the work dissolves and it becomes increasingly difficult to tell the difference between an ordinary thing and a work of art, when an event, which seems confusingly similar to an ordinary everyday activity, is a performance, then we are in the times of atmospheres.

17 For aesthetics of atmosphere, it is the social function of art to develop human sensuality, to teach us how to deal with atmospheres. The point of museums is that atmospheric experience can be acquired in a surrounding relieved from action, which is not possible in commercial shopping malls or churches, where the atmospheric experience is meant to bring us into a buying mood and religious captivation, respectively (Böhme, 1995, p. 16).

\section{Architecture and atmosphere}

18 "Forget the form," says Peter Zumtor (1998, p.96). It is the light, the mood, atmosphere, and bodily state of being that matter in his architecture. To describe architecture, one should use words such as "feeling or atmosphere or vibration or soul, etc., all of these old-fashioned words linked to Romanticism" (Zumtor, 1998, p. 99). Atmosphere was central as well for Frank Lloyd Wright. "Whether people are fully conscious of this or not, they actually derive countenance and sustenance from the 'atmosphere' of the things they live in or with" (Wright quoted in Wigley, 1998, p. 19). For Gottfried Semper, architecture was "a stage set that produces a sensuous atmosphere" (Wigley, 1998, p.20). Modernist architects rejected the concept of 
atmosphere. Atmosphere was taboo for mainstream reductionist, rationalist, and mechanical modernists. Many modernist architects were nevertheless absorbed by the atmospheric. The rejection of the scenic and ornamented, of clunky interiors, was less a matter of "eliminating all atmosphere than with creating those that were more lyrical, emancipatory, and in accord with the zeitgeist" (Buchanan, 1998, p. 81). If architecture is more than just construction, technique, and function, so it is, perhaps, just as the art of building, a paradigmatic, atmospheric art form. Along the same lines, the movement of art toward the atmospheric can be seen as the architecturalization of art.

What is atmospheric in architecture, however, is not only lyric. As Böhme (1995) stresses, it may be genuinely political. In churches, "atmospheres of holiness and humility" are created, courthouses and castles produce "atmospheres of domination ... which make social hierarchies sensuously manifest." Thus, what kind of society we live in depends also on architecture (p. 18).

To be sure, architects solve factual-functional problems and predefine the physical properties of things, but they also design physiognomies and atmospheres. They create space "with a particular atmospheric quality, atmospheres. Buildings, interiors, squares, shopping malls, urban spaces, airports and cultural landscapes can be uplifting, disheartening, bright, cold, good-humored, festive, factual; they can radiate a dismissive or a welcoming, an authoritative or a familiar atmosphere" (Böhme, 1995, p. 97). Organizing atmospheres, therefore, also generates atmospheric power. This power operates neither by physical violence nor commandments, but "grabs hold by the people's state of being, works on dispositions, manipulates moods, evoke feelings" (Böhme, 1995, p. 39). Thus, atmosphere is a concept for that which one could call atmospheric sociality, for the relations among human beings that are constituted by the contribution of the surrounding physiognomies.

\section{The mood of landscape and mental life of the metropolis}

In his essay "The Philosophy of Landscape" Georg Simmel relates the concept of landscape to moods. Landscapes are moods and the concept of landscape apparently refers to atmospheres. Nonetheless, there are crucial differences between an atmospheric approach and that of Simmel. We must dwell on those differences here, since they contribute to an understanding of why one of the grounding fathers of urban sociology never mentioned urban atmospheres despite his strong interest in aesthetics.

A landscape is neither a nature nor solitary thing in nature. To look at a "piece of ground and what is on it as a landscape means that one now conceives of a segment of nature itself as a separate unity" (Simmel, 2007, p. 22) This is, from the point of view of the concept of nature, strange, because nature consists of the "infinite interconnectedness of things" (Simmel, 2007, p. 21). The demarcated segment constitutes "a self-contained perception intuited as a self-sufficient unity," which is, however, as a segment of nature, "intermeshed with an infinite expansiveness and a continual flux" (Simmel, 2007, p. 22).

The ability to perceive a landscape as a self-sufficient entity occurs with modern individualization and differentiation. Individualization and "the dissolution of 
primordial ligatures into differentiated and self-contained entities ... resulted in our coming to recognize landscape within the realm of nature" (Simmel, 2007, p. 22). Modernization leads to "countless struggles and disunities in our social and technicalpractical, intellectual and moral lives" (Simmel, 2007, p. 23), but in relation to nature, it gives way to "the conciliatory richness of landscape [which is] something individual, contained, self-contented" (Simmel, 2007, p. 23).

When we observe a landscape, we do it as the artist, who marks a part out of the chaotic flux of the world and 'forms it as a unitary phenomenon,' which now 'derives its meaning from within itself' (Simmel, 2007, p. 23) We witness so far 'a work of art in statu nascendi' (Simmel, 2007, p. 25). Landscape, though, cannot be immediately understood as a developed and autonomous art, as, for example, landscape art. Art is " above the general perception of a landscape" (Simmel, 2007, p. 26). The question is, therefore, from where the unity of landscape comes. Simmel's answer is that it comes from the mood of a landscape, which "permeates all its separate components" (Simmel, 2007, p. 26). In a way that is difficult to specify, each constituent of a landscape takes part in the mood, which is "neither external to these constituents, nor is it composed of them" (Simmel, 2007, p. 26). As such, mood is grounded neither in particular things nor in their sum total; it is a surplus, something more, that makes things appear as landscape. So far, Simmel's concept of landscape is similar to atmosphere. But Simmel's approach to the mood of a landscape, which is justified objectively, with reference to the landscape itself or to a mental state that resides "in the emotional reflexes of the beholder" (Simmel, 2007, p. 27), moves in another direction. It is Kantian in that the mood achieves its "objectivity as landscape" due to "our formative acts" (Simmel, 2007, p. 28). We can never regard landscape "as a mere external entity;" landscape "exists only through the unifying powers of the Soul" (Simmel, 2007, p. 28). The objectivity of the mood is due to object-constituting subjectivity. Hence the question of where the unity of landscape comes from is answered: "both the unifying move which brings landscape as such into being, and the mood that a landscape projects at us and through which we comprehend it, are merely the result of a subsequent dismantling of one and the same psychic act" (Simmel, 2007, p. 27). In relation to the delimited mood, which we call landscape, "a perceiving and a feeling self" cannot be separated from each other (Simmel, 2007, p. 29).

27 Landscape as a unity of mood is derived from the perceiving feeling that creates this unity as its object. Nature and its objects are a condition for doing so, but do not contribute independently to the landscape-ness of a landscape. For Simmel, nature does not contain "in itself concise forms that can orient the mood of the subject in advance" (Hansen, 1991, p. 230). It contains only "the uninterrupted creation and destruction of forms, the flowing unity of an event" (Simmel, 2007, p. 21).

Thus, for Simmel, there are no ecstasies or physiognomies in nature (cf. Böhme, 1995, p. 187, for the opposite view). On the contrary, Simmel contrasts landscape, whose elements can, in our perception, be grouped together "in this or that way," with human figuration that synthesizes itself from its own forces around its own center and thus delimits itself unambiguously whereby a person's physiognomy approximates a work of art (Simmel, 2007, p. 25-26). If there were physiognomy in nature, so it would also look like a work of art, which, precisely, it does not. 
el's Kantianism and art-orientated determination of the unity of landscape therefore support each other. Along the same lines, he insists that mood can only secondarily be described with general and typical concepts, e.g., cheerful, serious, heroic, monotonous, lively, melancholic. A landscape is an individual unity of mood. The mood of a landscape is a mood that pertains to "just this particular landscape and never to any other" (Simmel, 2007, p. 28). Also in this way, landscape is similar to artwork. Types of moods, which can be generated by organizing certain characteristic physiognomies, such as, for instance, in gardening and scenography (cf. Böhme, 1995, p. 36 and f.), do not satisfy Simmel's art-orientated concept of mood. Typical moods would fall under the category of style and, thus, under art craft, not under art, and neither in its statu nascendi (cf. Nedelmann, 1991, pp. 181 and ff.).

have seen, Simmel contrasts the mood of a landscape with the battles and schisms of modern life. If fighting and divisions have a place, then it is the modern metropolis. Here reigns, as is well-known, the "uninterrupted change of outer and inner stimuli" (Simmel, 1969, p. 48). This is something quite different from "the sensory foundations of psychic life" in the small town and country life where the rhythm of everyday life "flows more slowly, more habitually, and more evenly" (Simmel, 1969, p. 48). Hence the "sophisticated character of metropolitan psychic life" is in contrast to life in small towns, which "rests more upon deeply felt and emotional relationships" (Simmel, 1969, p. 48). In the big city, intellect rather than emotions must prevail as protection against threatening circumstances and discrepancies (Simmel, 1969, p. 48). Here there is not much space where perception and feeling can coincide. As David Frisby has noticed, Simmel effectively declares in "The Philosophy of Landscape" that the cityscape of a metropolis cannot be a landscape (Frisby, 1991, p. 86). If a city looks like anything in Simmel's essay, it is, rather, nature.

\section{Urban atmospheres}

What then, precisely, are urban atmospheres? Can modern cities have distinctive moods or atmospheres, contra Simmel? If one puts aside the Kantian and art-orientated categorization of the atmospheric, so it might be possible to trace the atmospheric in the city as well.

\section{Smell, sound, and form of life: City life as a generator of atmosphere}

To grasp what urban atmospheres can be, it is useful to take the multi-sensory nature of atmospheres as a starting point. Böhme (2017) highlights in his essay "The Atmosphere of a City" that the Parisian atmosphere, as it once was, for him, is closely associated with the sense of smell, namely, with the smell of the Metro. Odors are an essential element of a city's atmosphere, perhaps the most essential, says Böhme, because they, more than any other sensuous phenomena, constitute "that quality of a surrounding which most intensely allows us to sense through our disposition (Befinden) where we are" (p.337). This applies regardless of whether the odor is pleasant or not. There is (still) a lignite scent of difference between East and West Berlin (Böhme, 2017, p. 337), and I myself remember a (not very pleasant) odor from the Oil Mill in Aarhus as a characteristic, location-identifying feature of the inner city until a few years ago. The odor-free city would be missing an important atmosphere-creating 
element: "A city without an odor is like a person without a character" (Böhme, 2017, p. 339).

Its sounds and acoustics belong to the atmosphere of a city, too. Not the sounds measured in decibels in order to bring noise levels below the limits of irritability and health hazards, but the character of the sounds, the diverse composite soundscape, that emerges from the city's miscellaneous activities, human and non-human. To Venice's specific atmosphere belongs, I think, the sound of footsteps, voice, and splashing water unmixed by engine noise from cars. Similarly, attempts have been made to describe the differences between sound-atmospheres in Lausanne in the French, Locarno in the Italian, and Zurich in the German regions of Switzerland, and between pedestrian zones in different German cities (Böhme, 2017, p. 295).

Thus the atmosphere of a city emanates not only from the character and physiognomy of the built-up mass, but also from its activities. Urban life forms generate not only urban sociality, but also urban atmospheres:

It makes a difference whether it is customary for people to honk their horns or not, what make of car they drive, whether radio music can be heard through their open windows, whether the names of goods are shouted out, or "alluring" music comes from the boutiques... The inhabitants of the city are also, always, producers of its atmosphere. (Böhme, 2017, p. 295-296)

A multi-sensorial disposition should therefore be able to sense atmospheres, which can be described as characteristic of a city, as that which makes the city singular and peculiar (Böhme, 2017, p. 288). No doubt, one can trace the diverse atmospheres in different areas of a city: the atmospheres of port areas, the central railway station, the city's nightlife, the commercial zones, transportation nodes, market squares, different housing areas, and industrial districts. The atmospheric breakdown of a city, that is, the demarcation of areas where different types of atmospheres are sensed particularly intensely, can follow quite other routes than those one would take from within an architectural and urban historical, iconographical, or a sociological perspective (Knodt, 1994, p. 54-56). The Situationists even envisioned a reconstruction of the city following an atmospheric differentiation made on the basis of careful "psychogeographical" analyses. We should take as starting point and develop the atmosphere-generating elements of the city, which the Situationists found in the decoration of a city, with a critical distance to the modernists. The city should be turned into a machine for the production of discrete and varying atmospheres (Wigley, 1998, p. 24 and f.). Constant envisioned a future urban fabric consisting of huge contiguous buildings raised above the ground; buildings, which had to be segmented in varying volumes linked by an interplay of stairs, landings, and corridors. This would result in a "diversity of different atmospheres" whose character can be affected and determined by manipulating colors, sounds, light, climate, and by making use of various "technological apparatuses and psychological processes" all in harmony with the inhabitants' own "experimental life games" (Constant, 1964, p. 171, cf. Heynen, 1999, p. 148-192).

\section{Atmosphere of the modern city}

The situationist critique of modernism in architecture and urban planning is easy to understand in the prism of an atmospheric approach. The functionally segregated city with its sterile buildings and developed traffic systems appears at first glance to be a city with a standardized or, maybe rather, "sanitized atmosphere" (Knodt, 1994, 
p. 57). Richard Sennett speaks of "the neutral city," which can be summed up in grids: horizontal as urban design, vertical as high-rise skyscraper (Sennett, 1991, Chapter 2). The modernist insistence on universal form and functional segregation has created urban areas that have turned characterlessness into character and facelessness into a facial feature. If this modern city has an atmosphere, then it is an atmosphere that points to our sensuous mode of living with things in a properly practical manner, a type of surveillance, or "institutional atmosphere", which tells us that we must do things right (Knodt, 1994, p. 59 f).

In the modern city, buildings change "from edifice to device, from buildings with distinctive personalities to standardized containers" (Kupfer, 1990, p. 319). Moreover, the city no longer consists of a dense, coherent building mass that encloses the street system, but of solitary containers submerged in a blank space structured by a raster system of traffic connections and functionally specific land use zones (Bæk Pedersen, 1998). A dense city's building masses are interrelated, endowing its public spaces with physiognomy, character, and atmosphere. A modern city's buildings are stand-alone volumes in an atmosphere-less blank space of transport links.

This is how the modern city can appear at first sight. Upon closer inspection, however, the matter is more complicated. Modernists, too, as already mentioned, had a sense for atmospheres. The semiotic and hermeneutic minimalism of modern architecture was not only about atmospheric standardization. To be sure, modern architecture sought to neutralize meanings and symbols, but in many modernist buildings the sensualaffective aspect of architecture was intensified. The same is true, to perhaps an even greater degree, regarding contemporary modernism, or, as Hans Ibelings (1998) has called it, "supermodernism" (Perraut, Nouvel, Zumtor, i.a.). Neutral modernism " prioritizes direct experience, the sensory experience of space, material and light" produced through "the super-cool transparence and smoothness of glass buildings" and "the tactile massiveness of ... sculptural volumina." The impression this architecture makes is created not by articulating messages, but at another, emotional, level "by the atmosphere" (p. 89, 94). If atmospheric art approximates architecture, so parts of architecture also approximate atmospheric art.

If many experience modern urban areas as unpleasant to live in, one explanation for this might be that architects and planners have not been sufficiently aware of the fact that the atmospheric effect is enhanced - for better and for worse - by the apparent neutrality of the architecture. Paradoxically, neutral architecture demands more, not less, atmospheric caution. The classical modernists were aware of this and the supermodernists remembered it under new conditions, but it was forgotten in many buildings from the 1960s and 1970s.

In the modern city one can thus find an architectural atmosphere. Does an urban atmosphere also exist? The modern city's scattered buildings do not amount to something reminiscent of the atmosphere-generating physiognomic constellations of the dense city. The "leaking" city (Nielsen, 1998, p. 1) seems without urban atmosphere, precisely because it is not dense. When Rem Koolhaas claims that "we are left with a world without urbanism, only architecture, ever more architecture" (Koolhaas and Mau, 1995, p. 967), he reflects the tendency of urban atmosphere to be replaced with architectural atmosphere in the modern city.

41 The atmosphere of an urban setting can also be replaced with another, new type of quasi-urban atmosphere, namely the atmosphere in a very large building, which is 
internally articulated like a dense urban street network. A major commercial center compensates for the lack of atmosphere in the modern city by incorporating urban atmospheres under its roof. Koolhaas argues:

Beyond a certain critical mass, a building becomes a Big Building. Such a mass can no longer be controlled by a single architectural gesture, or even by any combination of architectural gestures. ... Issues of composition, scale, proportion, detail are now moot. The "art" of architecture is useless in Bigness. (Koolhaas \& Mau, 1995, p. 499 and f.)

It is this quasi-urban that stands in the way of architecture. Hence, paradoxically, the equation "Bigness = urbanism vs. architecture" (Koolhaas \& Mau, 1995, p. 515), even though we live in a world without urbanism. It simply has moved inside.

Architectural atmosphere and extra-large buildings' quasi-urban atmosphere do not, however, empty out the atmospheric spectrum of the modern city. The quotation above is missing an important element related to life form, human actors' mobility in the transportation infrastructure. If we continue to assume that an urban atmosphere requires the dispositional encounter between sensing human bodies and an environment marked by ecstasies, character, and physiognomy, one could claim that what is atmospheric in the modern city is perhaps first and foremost the sensory experiences attached to the motorized motion around the traffic system of an urban region. The rapid movement (or specific viewpoints) can, for the sense of sight, bring the solitary objects of the regional network together in an ecstatic relation, producing an atmosphere of urbanity in the vast network of the modern city.

\section{The cyborg's picturesque cityscape}

The "leaky" city has thus a certain atmospheric similarity with the dense city because of mobility. But the total urban landscape or the urban 'field' (Nielsen, 1998, p. 1, cf. Østerberg, p. 81 and Lash, 1999, p. 59-65) is not a dense city. The urban field consists of the dense city, container-raster systems and landscapes. The city has grown into the country and the country into the city, and this marks the tissue of the city, its material structure, with a discontinuous character. In relation to this phenomenon, the paradigm of the dense city seems to be of limited value for a description of urban atmospheres.

In this urbanity of discontinuity, urban atmospheres assume new discontinuous forms. Mobility can of course bring together the disparate containers in an atmospheric constellation, but mobility is first and foremost movement through a discontinuous landscape. The atmosphere of mobility is an atmosphere of leaping, of the rapid shift from one atmospheric constellation to another. To use a term from philosophical aesthetics, for lack of a better option, the urban field as a whole has neither the continuous physiognomy of the beautiful nor the delightful and fearsome richness of the sublime (cf. Lash, 1996), but rather the character of the picturesque, which is characterized by "heterogeneity, excessive change, disorder and incongruity" (Ibelings, 1998, p.135). A picturesque landscape is an alternating landscape that switches between the sublime and the beautiful (Nielsen, 1998, p. 4 and f.). The modern urban field, in turn, is the field of the picturesque atmosphere, the field for the atmosphere that forms itself by ever-changing atmospheres. A 'meta'-atmosphere's atmospheric characteristic is the change of atmosphere, not unlike the Situationists' 
notion of the city as a generator of discrete and varying atmospheres, but quite without the utopian content.

Who has a sense for this picturesque atmosphere? Many will certainly only perceive atmospheric differences and consider the urban field as disjointed and fragmented in terms of atmosphere. Others who have grown up with the practice of flicking through TV channels or of leaping from site to site on the internet might sense the mood in the very atmospheric shifts. The city, which has spread out as a cityscape since the 1960s, will perhaps prove to be aesthetically prepared for the new and emerging cyborggenerations:

Aggressive, difficult to decipher, decoupled from biological rhythms, the contemporary city sometimes seems to be created for advanced cyborgs who are equipped with a different perception of space and time than its ordinary inhabitants. [...] [T]oday's urban territories present themselves as juxtapositions of entities that often lack direct connections with each other, residential areas, commercial centers, railway stations and airports, industrial zones, which are served by infrastructures, railways, roads and highways, which place everincreasing demands on land. Unlike the traditional urban space, the contemporary city can no longer be walked in all directions (Picon, 1998, p. 23 and f.).

Simmel would hardly recognize mood in this sense. His metropolitan type would react against the sudden differences with intellect. A cyborg, as a human "differentiating creature", in contrast, would sense the mood in "the rapid crowding of changing images, the sharp discontinuity in the grasp of a single glance, and the unexpectedness of onrushing impressions" (Simmel, 1969, p. 48).

\section{Neighboring community, age of urban architecture, and age atmospheres}

The urban field does not consist only of the dense city and containers enshrined in raster systems. And the reaction to modernism's atmospheric sanitization did not consist only of the post-modernist semiotic rehabilitation of classic architectural symbols (Robert Venturi) and the neo-rationalist reactivation of classical ideals of the dense city in accordance with the hermeneutics of depth (Aldo Rossi). One turned back to the village as well. Since the early 1970s, the urban fields in Denmark have been enlarged with dense, low-rise suburban housing areas. Such enclaves have village-like façades and a village community atmosphere. Their density, small scale, and relative enclosure give these enclaves an atmosphere of community. Clearly, this mood corresponds in many cases to a real social community. But in the urban field, community relations are, apart from ghetto formation, rarely tied to locality. Rather, they expand in network relations that reach out in the entire field (Fischer, 1982). Nevertheless, many prefer low-density housing. There can be many different reasons for this. One might be the atmosphere of community. The neighborhood can act as an aesthetic of community, as a perceived state of being rather than as a framework for an active social community.

Regarding the dense city, the concept of urban architecture has in recent years gained growing attention among urban planners in Denmark. The term refers to the constellations of which the buildings of the dense city, their surfaces, and façades are a part. The architectural aspect in urban architecture is concerned not with the buildings 
of the city separately, but with the physiognomy that they constitute together. Urban architecture is defined, for example, as follows:

Architecture is the notion we use when a building - in addition to satisfying a range of technical and functional requirements - offers the user or the spectator an artistic experience. Urban architecture is the corresponding notion in the case of a complex of buildings, a street, a town or an entire city. That a variety of houses in a street together constitute a whole, for instance, can evoke an artistic experience ... [T] he impression of wholeness and coherence can be due to the fact that the buildings have, for example, the same proportions, that the roofs have the same slope, or that the houses have a bricked cornice. Or maybe the various buildings are bound together by a hurled, historic streetscape. (Holmgren \& Svensson, 1991, p. 7)

Artistic experience suggests conceptual embarrassment. The point of the concept of urban architecture must be that urban architecture exists in constellations and character traits of an area, which are neither experienced as art nor have to be the result of an overall artistic intention. On the contrary, urban architectural wholes will often be the outcome of different contributions of different architects, property developers, and builders to the whole through different historical periods. The experience an urban architectural physiognomy can instigate is rather an atmospheric experience, and it is these urban atmospheres that the world of planning has found essential to preserve.

51 To maintain an urban atmosphere is not necessarily an expression of restorative interest or necessarily a sign of nostalgia or fixation on local identity as a consequence of interurban competition in rootless times. Urban atmospheres can be preserved, despite new buildings being added to the built environment, on which Holmgren and Svensson provide advice, and there can be good reasons for it, even though the related physiognomy is perhaps not genuinely local or has significant historical interest. Only the mood in the cityscape can be a sufficient reason.

The restoration of a city's buildings is, however, often to preserve buildings that have architectural or cultural-historical value. Yet there is also a historical dimension to the city that is not related to architectural or cultural-historical knowledge, but to the capacity to sense the age of the city. Böhme calls this a city's historical depth (1998b, p. 60). It was probably something similar that Alois Riegl (1903) had in mind when he proposed "age-value" (Alterswert) as a criterion for conservation. Here, the value is grounded in the fact that one can see and sense that the thing is old. Such value can be "experienced without scientific prerequisites, it requires no prior knowledge acquired through historical formation" (Kirkeby, 1998, p. 66). Such phenomena can be called the city's age-atmospheres.

53 New architecture can be inserted in a present physiognomy in a way that allows for retaining the atmosphere. But new architecture can also destroy a physiognomy and thus an urban atmosphere. Much opposition to modern architecture in the atmospheric spaces of the dense city seems to have been triggered by such devastation. Atmospheres take hold of dispositions. Atmospheric disturbances can, therefore, arouse strong feelings. There is a politics of atmosphere.

\section{Atmosphere of conflict: The City Hall Square in Copenhagen}

54 A striking example of a political dispute, which seems to have a powerful atmospheric content, can be found in the City Hall Square (Rådhuspladsen) in Copenhagen. It 
concerns the dispute over the new HT-bus terminal at the square. From an urban architectural perspective, the City Hall Square and its surrounding buildings is marked by a certain unity and wholeness. Buildings, in their mutual constellation, play together, form a physiognomy, and provide the square with an evident disposition despite its size and traffic load. The building mass around the square is "relatively uniform in terms of scale." There are "manifest differences in style, materials and decoration," but "the lengths of façades and cornice heights, window size and divisions, and so on, recurring from house to house." This "common scale is underlined by the towers' vertical shooting of the scale: City Hall's withdrawn tower, the Palace Hotel's middle position and sleekness, the round-shouldered character of the Aktuelt building, and the Richs building's low-key quality. On the other hand, the HT building, which falls out of scale in a quite inelegant way, weakens the connections" (Ovesen, 1998, p. 7).

55 The HT building has provoked such strong dispute and opposition from the public and local politicians that the building might be demolished. Copenhagen's City Council allocated 5 million Danish kroner to the budget for the year 2000 to demolish the terminal. Time will tell whether it will be realized, ${ }^{3}$ but it seems natural to interpret this dispute as a consequence of the fact that the building breaks with City Hall Square's atmosphere. The building does not integrate into or interact with the overall physiognomy of the surrounding buildings. The terminal's location is certainly wellchosen, as it improves the proportions of City Hall Square as a square (Ovesen, 1998, p. 5). But in relation to the dimensions of City Hall Square and the building behind it, the terminal building is too low and it is characterized by an unfinished-ness that emphasizes "the spatial diffuseness of the site" despite intentions (Ovesen, 1998, p. 10). In addition, with its modernist simplicity and dark façade, it stands out markedly from its surroundings.

\section{Urban atmospheres and imaginary city centers}

Koolhaas uses the term "generic city" to designate a metropolitan region's urban field. A generic city is not organized around an identity-creating center, but "liberated from the captivity of center, from the straitjacket of identity. The Generic City ... is nothing but a reflection of present need and present ability. It is the city without history." The center is therefore also no longer "the real center," but an "overblown mirage on the way to implosion," an "illusory presence." Nevertheless, these centers are maintained, particularly in European cities. The illusory center dominates the rest of the city by denying its legitimacy and attracting resources. It must constantly be maintained and modernized. "As 'the most important place,' it paradoxically has to be, at the same time, the most old and the most new, the most fixed and the most dynamic" (Koolhaas \& Mau, 1995, p. 1249 and f.).

Dag Østerberg seems to think along similar lines in his book on Oslo. Oslo is not a city clearly demarcated from the country. This is an "obsession which we must liberate ourselves from." Oslo, on the contrary, is a region, a condensed "socio-material field of action" divided into different layers, or sediments, that are linked together by traffic systems (Østerberg, 1998, p. 27, 34). It is not obvious, according to Østerberg, that this regional, socio-material network "must have a midpoint, a center". Contrary to this hopeless idea (Østerberg, 1998, p. 136), the historic center is fast becoming an imaginary 
socio-matter, a place that primarily appeals to fantasy. It is no longer a real power center or a public political space, but an "imaginary recreational machine, that is, the compensation for an oppressive everyday life that is experienced as real" (Østerberg, 1998, p. 129 and f.). If Oslo exists as a city, it exists alone in the memory, in fantasy, and does so as a city for others. The city exists as "materialized memories of the urban-ness of the past" that appear in various (disciplinary, bourgeois and the functionalist) sediments (Østerberg, 1998, p. 42-59). It is found in "materialized fantasies and as fantasies of the soul," that is, as stagings of past city life and as the imaginary community of evening and nightlife, and in the area domestic and international tourists perceive as Oslo. For them, Oslo appears as a "demarcated entity with a center determined by main streets and special attractions, by the fjord and the ridges" (Østerberg, 1998, p. 142).

Christian Norberg-Schulz has opposed this description of Oslo in a review of Østerberg's book. Østerberg fails to understand that there exists a holistic site use, which is constitutive of community and "traverses economic and political dividing lines, and enables us, today as before, to define our identity with reference to the place." The socio-matter, therefore, does not cancel out the difference between rural and urban areas, either. "It is fortunately still possible 'to be in the city' or to 'go into the country," also for the inhabitants of the Oslo region (Norberg-Schulz, 1998).

What can the concept of atmosphere contribute to this discussion? Is the urban atmosphere of the center only a fantasy? Does the city of Oslo exist only as a memory, as fantasy, and for others? Or is there, on the contrary, holistic, communitarian site use? Let us start with fantasy. Østerberg assumes that there is an essential difference between inhabitants and tourists' perceptions of Oslo. "The field of the inhabitants and the field of the others" are decisively different because the latter is not related to work and duty. Tourists experience the field in their spare time and can concentrate on attractions. For inhabitants, on the other hand, the field appears in the light of their daily preoccupations, which is to say that the socio-material for them constitutes "an obscure wholeness of common and particular experiences" determined by their "patterns of belonging, tasks, duties and rights, through which they are, for better or worse, relegated to the field." The imaginary field is generated through the mingling of the two fields, whereby it appears "as if the inhabitants perceive, experience the field in the same way as tourists, which is impossible in reality but possible, precisely, in fantasy." Through this confusion one can get the impression that "the pedestrians, cyclists and car drivers together amount to a whole, a 'swarming street life', a 'spirited population,' a 'colorful community." However, things only appear this way in the tourist's gaze (Østerberg, 1998, p. 104-107).

When we speak in common parlance or write in tourist brochures about an atmosphere as characteristic of a city, it is because, according to Böhme (2017), we usually adopt the stranger's perspective. But the atmosphere a stranger perceives is not the city considered from a tourist perspective. On the contrary, the atmosphere is "that which is commonplace and self-evident for the inhabitants and which is constantly produced by the locals through their lives, but which is noticed first by the stranger as a characteristic" (p. 288). For Østerberg, such a perception may be due to the confusion of the two fields and, accordingly, characteristic atmosphere must be an imaginary phenomenon. Böhme, on the other hand, will insist this is sensed mood, not pure fantasy. The stranger is struck by the atmosphere, which is characteristic of the city's 
way of life and which inhabitants, absorbed by daily preoccupations, perhaps need to be made aware of to feel it. Between the burdens and demands of everyday life (Østerberg, 1998, p. 107) and the stranger's free experience of the city, there is a third phenomenon, namely atmosphere, which is created by the life and activity of the sociomaterial field. One does not have to live a permanent resident's life to sense this urban atmosphere, but one has to have a sense for more than the attractions of a city. If a tourist senses the characteristic atmosphere in central Oslo, it can be because it is there. But perhaps, as an inhabitant of Oslo, Østerberg should be made aware of this.

Concerning the city as memory, Østerberg also seems to miss the atmospheric. Sociomaterial sediments each have their historical origin and are reminiscent of the past. They enable us, as he writes, "to 'imagine in the fantasy' or 'feel in the body' how people in the costumes of the past have lived in this socio-matter." One can therefore "have a crush on the socio-material remainders of earlier social life" or mourn the lost opportunities (Østerberg, 1998, p. 107). No doubt about that. But there is also an atmospheric aspect to the history of these sediments, which is reducible to neither fantasy saturated by historical knowledge nor knowledge of the historical-political coding of the sediments (Østerberg, 1998, p. 38 and f.), but which is about the physiognomy and character rising out of the fact that they are old today - Böhme's historical depth and Riegl's age-value. This actuality of the historical is not only a mediator for remembrance and political codification, but also a perceived presence of historical processes that help create the urban atmospheres of the Oslo region for those who move in it every day.

62 If the atmospheric is involved, the concept of the city does not seem to be reducible to fantasy, memory, and the city for others. One can find urban atmospheres in the total socio-material densification, which is constituted by the entirety of the Oslo region. I certainly cannot decide whether or not these unite one or more characteristic of Oslo's atmosphere(s), but it cannot be ruled out, either, that it could be the case. An Osloite cyborg might sense the picturesque atmosphere of the region. The historic center is probably rather illusory as the functional center for the metropolitan region. But that does not mean that it cannot be the atmospheric center for Oslo's inhabitants, as well. Let me illustrate this with an example from Aarhus, from the night in 1992, when the Danish team won the European football championship. That night, many people spontaneously gathered in the main square in front of Aarhus Cathedral. No one had called for the gathering, but everyone knew where the center was. They came in cars from the suburbs. It was hardly the knowledge of the history of Aarhus that was the driving force; rather it was the square's historical depth, its age-atmospheric meaning for the Aarhusian identity of the city and its inhabitants.

63 Are we, then, faced with Norberg-Schultz's holistic site use, which grounds a community and which provides the region and its inhabitants with identity? Hardly. The metropolitan region is a heterogeneous and fragmented entity, and the use of the site is diverse, just as communities are. Many will have "common orientation points" (Østerberg, 1998, p. 104) in this socio-material action field, but it hardly amounts to a unified pattern of use. Yet, Oslo's inhabitants probably feel an atmospheric community. As Østerberg (1998) writes in general about the inhabitants' field of action: "For the majority a certain experience of the environment will also be common, whether the socio-material is more or less light or heavy, high or low, whether it is surrounded by mountains or sea, of cultivated fields, or woods and fields, 
whether the number of inhabitants is high or low" (p. 104, emphasis added). More could be added regarding the Oslo region. This commonality of experience could amount to such an extent of atmospheric identity that many can sense where Oslo approximately stops and where the country begins.

\section{Urban morphology and urban sociology}

As can be seen, there are rudiments of descriptions of atmosphere in Østerberg's work. Large parts of the chapter on experiences of "burden and relief" (Østerberg, 1998, p. 60-108) can actually be read as descriptions of atmosphere, since they precisely relate to the bodily state of being in a big city. This applies in particular to the description of "experiences of loaded-ness" in a city's systems for physical mobility (Østerberg, 1998, p. 60-71), and when he describes Manhattan's massiveness as "bleak and oppressive, even though it was far from intentional," and claims that Stockholm "on the whole seems heavy on Norwegians, a 'stone desert"' (Østerberg, 1998, p. 74 and f.). Here we see Østerberg's sense for atmospheres. But this sense is kept in check by three theoretical limitations.

Firstly, the governing distinctions between burden and offload, facticity and liberty (Østerberg, 1998, p.29), are hardly adequate in relation to the diversity of atmospheres. Secondly, the emphasis is heavy on semiotics. This causes a strong tendency toward the reduction of atmospheres to semiotic codes. Heavy buildings exude not only an atmosphere of solidity. As churches, they demand awe, as schools do servility, and banks command respect for wealth (Østerberg, 1998, p. 75). I do not deny that this may be true, but it hardly exhausts the atmospheric significance of buildings. One who lacks reverence for a church, servility in relation to a school, and respect for wealth at a bank will continue to be able to feel what Østerberg calls "the value" (lødighed) of the buildings (Østerberg, 1998, p. 75).

And thirdly, aesthetics are considered within the paradigm of art. Aesthetics belong in the offloaded sphere of freedom. The aesthetic way of seeing a city:

follow[s] the lines as well in the individual building as in the entire quarters and larger areas. It listens to this "frozen music," its themes and variations, its counterpoints and circlings. It interprets ... the common meanings ... "reads" the rows of houses and the standalone constructions, reads the street network and the concentric ring roads. ... Aesthetic approach requires free time or liberation from the demands of other people or the socio-material. Here the presence of one's fellows is not felt. It is ripped out of attention. Here one is alone with the sociomatter as a field of signs and meanings, which one freely and without restrictions can devote one's attention, beyond burdens and demands. (Østerberg, 1998, p. 92 and f.)

Here, the aesthetic is reduced to relief from action provided by a museum and to semiotics and hermeneutics, although it also claims that the aesthetic approach is really about "our ability to sense and its relation to the socio-material" (Østerberg, 1998, p. 92 and f.). But the socio-matter is not just a field of signs and meanings, it is also a field of physiognomies, ecstasies, and possible atmospheres that one can sense in one's everyday state of being, not standing alone vis-à-vis materiality, but socially, together and in interaction with other people. The question of atmosphere emerges, as Pauline von Bonsdorff (1998) highlights following, among others, Merleau-Ponty, "in awareness of others: humans, animals, trees or expressive artefacts" (p. 139). In this sense, the concept of atmosphere also allows for an extension of the concept of the 
social toward non-human actors, as Bruno Latour (1996) suggests, we "share the social with things" (p. 235, emphasis added). This is, however, more than an aesthetic problem.

Urban morphological and urban sociological studies rarely play well together. The first cares most for the accumulation of buildings and infrastructure whereas the second cares most for the accumulation of people. Østerberg's socio-material perspective is an excellent demonstration of the fact that it does not need to be so. Also, in Østerberg's universe, things do something. The idea that socio-matter "in a way address the people in the field, who answer back through their behavior" (Østerberg, 1998, p. 27, emphasis added) is extraordinarily fruitful, but it needs more atmosphere.

Donec et nisi at leo rhoncus facilisis. Donec at urna. Sed commodo dolor vitae leo. Pellentesque habitant morbi tristique senectus et netus et malesuada fames ac turpis egestas. Sed nec justo. Maecenas eget turpis. Integer purus diam, bibendum et, sagittis sit amet, vehicula quis, velit. Nunc velit pede, pharetra vitae, placerat in, faucibus eget, eros. Praesent et libero non odio dapibus lobortis. Donec vestibulum. Donec lectus ante, volutpat lobortis, euismod quis, aliquam at, enim. Sed laoreet consequat libero. Donec volutpat laoreet enim. Cras pellentesque fermentum nibh. Duis purus. Etiam laoreet dui nec purus. Aliquam ipsum dui, scelerisque quis, viverra pulvinar, tristique vitae, neque.

Phasellus ultricies congue sem. Nulla malesuada sem. Suspendisse potenti. Duis mattis. Sed dictum iaculis tortor. Duis aliquet, pede sit amet tincidunt scelerisque, diam pede tristique metus, et dignissim nisl nulla eget tortor. Phasellus sagittis felis ac tellus. Suspendisse ac nisi. Maecenas vitae augue. Aenean aliquet massa a elit.

\section{BIBLIOGRAPHY}

Adolphe, Luc. 1998. La recherche sur les ambiances architecturales et urbanes. Les cahiers de la recherche architecturale, 42/43, p. 7-11.

Albertsen, Niels. 1993. Byen, det sociale og retorikken. In: Christensen, Christa Lykke \& Thau, Carsten (eds.). Omgang med Tingene. Aarhus: Århus Universitetsforlag. p. 181-202.

Böhme, Gernot. 1993. Atmosphere as the Fundamental Concept of a New Aesthetics. Thesis Eleven. Vol. 36 (1), p. 113-126.

Böhme, Gernot. 1995. Atmosphäre. Essays zur neuen Ästhetik. Frankfurt a. M: Suhrkamp Verlag. Böhme, Gernot. 1998. Atmosphere as an aesthetic concept. Daidalos 68, p. 112-115.

Böhme, Gernot. 2017 [1998]. The atmosphere of a city. In: Böhme, Gernot. The Aesthetics of Atmospheres. London: Routledge. p. 125-134.

Buchanan, Peter. 1998. Musings about Atmospheres and Modernism. Daidalos 68, p. 80-89.

Bæk Pedersen, Poul. 1998. Container og Urbant Raster. Aarhus: Aarhus School of Architecture (unpubl. manus). 
Constant. 1981 [1960] Neu Babylon. In: Conrads, Ulrich (ed.). Programme und Manifeste zur Architektur des 20. Jahrhunderts. Gütersloh: Bertelsmann Fachverlag, p. 170-71.

Fischer, Claude S. 1982. To dwell among friends: Personal networks in town and city. Chicago: University of Chicago Press.

Frisby, David. 1991. The Aesthetics of Modern Life: Simmel's Interpretation. Theory, Culture \& Society. Vol. 8(3), p. 73-93.

Hansen, Nils Gunder. 1991. Sansernes sociologi. Om Georg Simmel og det moderne. Copenhagen: Tiderne Skifter.

Heynen, Hilde. 1999. Architecture and Modernity. A Critique. Cambridge, Massachusetts: MIT Press.

Holmgren, Steen \& Svensson, Ole. 1991. Byarkitektur i kommunens planleggning. Hørsholm: Statens Byggeforskningsinstitut.

Ibelings, Hans. 1998. Supermodernism. Architecture in the Age of Globalisation. Rotterdam: NAi Publishers.

Kirkeby, Inge Mette. 1998. Mødet mellem nyt og gammelt. Bygningsbevaring i vor tid. Copenhagen: Christian Ejlers' Forlag.

Knodt, Reinhard. 1994. Ästhetische Korrespondenzen. Denken im technischen Raum. Stuttgart: Philipp Reclam jun.

Koolhaas, Rem \& Mau, Bruce. 1995. S,M,L,XL. Office for Metropolitan Architecture. Rotterdam: 010 Publishers.

Kupfer, Joseph. 1990. From Edifice to Device. Architecture of disengagement. Technology in society. Vol. 12 (3), p. 319-332.

Lash, Scott. 1996. The sublime and the informational city. In: Verwijnen, Jan \& Lehtovuori, Panu (eds.). Managing Urban Change. Helsinki: University of Art and Design, UIAH. p. 88-98.

Lash, Scott. 1999. Another Modernity, A Different Rationality. Oxford: Blackwell Publishers.

Latour, Bruno. 1996. On Interobjectivity. Mind, Culture \& Activity. Vol. 3(4), p. 228-245.

Luhmann, Niklas. 2000 [1995]. Art as a Social System. Stanford: Stanford University Press.

Nedelmann, Brigitta. 1991. Individualization, Exaggeration and Paralysation: Simmel's Three Problems of Culture. Theory, Culture and Society. Vol. 8(3), p. 169-193.

Nielsen, Tom (1998) Overskudslandskabet som byens attraktive og ubrugte resource. Paper to NSBB-Urban Forskning Seminarium, Helsinki 13.-14.11. Aarhus: Arkitektskolen i Aarhus.

Norberg-Schulz, Christian. 1998. Sorte Hull. arkitektnytt. 15, p. 10.

Ovesen, Hans. 1998. Det For (t)satte Rum-en arkitektonisk analyse af Københavns Rådhusplads. Copenhagen: Center For Tværfaglige Urbane Studier, Kunstakademiets Arkitektskole.

Picon, Antoine. 1998. La ville territoire des cyborgs. Besançon: Les Éditions de l'Imprimeur.

Riegl, Alois. 1903. Der moderne Denkmalkultus: sein Wesen und seine Entstehung. Wien: W. Braumüller. Sennett, Richard. 1991. The Conscience of the Eye. The Design and Life of Cities. London: Faber and Faber.

Simmel, Georg. 2007. The Philosophy of Landscape. Theory, Culture \& Society. Vol. 24(7 - 8), p. 20-29. 
Simmel, Georg. 1969. The Metropolis and Mental Life. In Sennett, Richard (ed.). Classic Essays on the Culture of Cities. New Jersey: Prentice Hall. p. 47-60.

von Bonsdorff, Pauline. 1998. Atmosphere: In the Phoric of Urban Metaphors. In: Haapala, Arto (ed.) The City as Cultural Metaphor. Studies in Urban Aesthetics. Lathi: International Institute of Applied Aesthetics. p. 126-143.

Wigley, Mark. 1998. The Architecture of Atmosphere. Daidalos. 68, p. 18-27.

Østerberg, Dag. 1998. Arkitektur og sosiologi i Oslo-en sosio-materiell fortolkning. Oslo: Pax Forlag A/ $\mathrm{s}$.

Zumtor, Peter. 1998. Questioning Images. Interview with Peter Zumtor. Daidalos. Vol. 68, p. 90101.

\section{NOTES}

1. I am obliged to thank the participants in the research project "Welfare City" at the Aarhus School of Architecture for insightful discussions of an earlier version of this article. Tom Nielsen's comments and suggestions were especially valuable. I am of course responsible for the use I make of the good advice. The Danish Research Councils and the Aarhus School of Architecture funded the project.

2. Some sociologists might worry about all this philosophizing. Let me therefore also refer to Niklas Luhmann, who, with a quite different theoretical starting point, explains the concept of atmosphere in this way: "Atmosphere is always what the individual objects that occupy places are not, the other side of their form, what perishes along with them. This explains the "invulnerability" of atmosphere, along with its dependency on a given occupied space. Atmosphere is a kind of excess effect caused by the difference between places. It cannot be analyzed by describing places, nor is it reducible to places. It comes into being each time an object occupies a place and creates an ambiance that is neither identical to the object nor able to exist without it. Atmosphere makes visible [...] the unity of the difference that constitutes space" (Luhmann, 2000, p. 112).

3. The HT-terminal was demolished in 2010 .

\section{ABSTRACTS}

Gernot Böhme proposes the concept of atmosphere as the basic concept of a new aesthetics without a point of departure in art. This article speculates on some possible urban implications of this concept. To start with, I present various ontological and epistemological aspects of the concept and specify some atmospheric dimensions of art and architecture. Then, I discuss Georg Simmel's concept of landscape, which seems to refuse the presence of atmosphere in the metropolis, as an overture to the next section on urban atmospheres. Urban atmospheres are multi-sensorial and demonstrate considerable variation from densely built inner-city areas to the modern spaces of urban sprawl. Mobility is a significant factor in relation to modern urban regions, the atmosphere of which might be thought of as a picturesque landscape for cyborgs. Urban communities may be of a primarily atmospheric kind. The historical city may have an 
atmosphere of age that can be sensed without much historical knowledge, and atmosphere may be the source of urban political struggle. Finally, I examine the atmospheres of the urban center and the urban region with a focus on Dag Østerberg's recent work on Oslo, arguing that atmospheric aspects of the socio-material action fields within the urban region may modify Østerberg's conclusions regarding the imaginary status of the center and the urban identity of the region. The pivotal argument of the article is that atmosphere is an important but overlooked dimension of both human relations in urban environments and the relationship between the human and the built environment.

Gernot Böhme avance le concept d'atmosphère comme la base d'une nouvelle esthétique qui n'aurait pas de point de départ dans l'art. Cet article étudie les potentielles implications urbaines de ce concept. Tout d'abord, je présente plusieurs aspects ontologiques et épistémologiques du concept et précise quelques dimensions atmosphériques de l'art et de l'architecture. Ensuite, j'aborderai le concept de paysage selon Georg Simmel, qui semble rejeter la présence de l'atmosphère dans la métropole. Cela servira d'ouverture pour la partie suivante, sur les atmosphères urbaines. Les atmosphères urbaines sont multi-sensorielles, et sont très différentes selon qu'elles se trouvent dans des zones densément construites au sein des villes ou dans les espaces modernes de l'urbanisation. La mobilité est un élément important en lien avec les régions urbaines modernes, dont l'atmosphère est pensée comme un paysage pittoresque pour cyborgs. Les communautés urbaines seraient principalement de nature atmosphérique. La ville historique peut avoir une atmosphère du temps passé, qui pourrait être ressenti sans connaissance historique, et l'atmosphère peut être une source de conflit politique urbain. Enfin, j'examine les atmosphères des régions et du centre urbains, en mettant l'accent sur les travaux récents de Dag Østerberg sur Oslo, et je soutiens que les aspects atmosphériques de l'action sociomatérielle en région urbaine pourraient modifier les conclusions de Østerberg sur le statut imaginaire du centre et l'identité urbaine de la région. L'argument majeur de cet article est que l'atmosphère est une dimension importante mais négligée dans les relations humaines au sein des environnements urbains et dans la relation entre l'humain et l'environnement construit.

\section{INDEX}

Mots-clés: ambiances, art, architecture, ville moderne, paysage, picturesque, Oslo, Böhme, Simmel, Østerberg.

Keywords: atmospheres, art, architecture, modern city, landscape, picturesque, Oslo, Böhme, Simmel, Østerberg.

\section{AUTHORS}

\section{NIELS ALBERTSEN}

Niels Albertsen (1945) studied political science at Aarhus University. 1975 - 2015 he was employed at the Aarhus School of Architecture, where he now is professor emeritus. Research has been into urban and social theory, architectural and design theory, the sociology of the architectural profession, the sociology and philosophy of art. He was the Head of the Department of Landscape and Urbanism (2003-2011) and Co-director of the Centre for Strategic Urban Research (2004-2015). He has published on atmosphere since 1996, most recently Atmosphere: Power, Critique, Politics. A conceptual analysis in Nicolas Rémy \& Nicolas Tixier (eds.): Ambiances, tomorrow, Volos, 2016. 